\title{
SELECTION INTENSITIES OF FAMILIES AND CLONES IN POTATO BREEDING
}

\author{
Intensidade de seleção de famílias e clones no melhoramento genético da batata
}

\author{
César Augusto Ticona Benavente ${ }^{1}$, César Augusto Brasil Pereira Pinto²
}

\begin{abstract}
Families selection has not been recommended as a selection method for vegetative propagated species. To verify its utility for potato improvement a series of experiments were carried out under warm temperatures (rainy season). Thirty clonal families originated from heat tolerant parents were evaluated for tuber yield and specific gravity. After obtaining the seedling generation (SG) and the first clonal generation (FCG) individual clones from a further two generations were assessed. Simulations were conducted with different intensities of family selection in SG and FCG and intensities of clonal selection in subsequent generations. The results show that family selection intensities between 50\% and 60\% allowed the greatest gains. Estimates of $h^{2}$ at the families level were always higher than at the clones level and corroborate for the more effective selection of families in early generations. The selection of families for tuber specific gravity can be made in the early generations (SG and FCG) regardless of the temperature conditions where the individual clones will be selected. The sequential selection of families with intensities of $60 \%$ (SG) and 60\% (FCG) would promote greater efficiency for the selection of clones in second or third clonal generation. In the case of applying stronger selection intensities for a higher efficiency with sequential selection (SG and FCG) weaker intensities should be applied in the SG $(\geq 60 \%)$ and stronger intensity in FCG $(\geq 40 \%)$. Family selection for tuber yield could be practiced in the FCG as long as the selection of clones was not held in contrasting temperature conditions.
\end{abstract}

Index terms: Sequential selection, computer simulation, Solanum tuberosum.

\section{RESUMO}

A seleção de famílias não tem sido um método recomendado para a seleção de plantas de propagação vegetativa. Para verificar sua utilidade no melhoramento da batata, realizou-se uma série de experimentos em condições de temperaturas elevadas (safra das águas). Trinta famílias clonais provenientes de genitores tolerantes ao calor foram avaliadas para produção e peso específico de tubérculos. Depois de obtidas a geração seedling (GS) e a primeira geração clonal (PGC) foram avaliados clones individuais, por mais duas gerações. Foram realizadas simulações de diferentes intensidades de seleção de famílias na GS e PGC e intensidades de seleção de clones nas gerações seguintes. Os resultados indicam que intensidades de 50 e $60 \%$ produzem os maiores ganhos. As estimativas da $h^{2}$ em nível de famílias foram maiores que em nível de clones, o que confirma a eficiência da seleção de famílias em gerações precoces. A seleção de famílias para peso específico pode ser realizada em gerações precoces (GS e PGC), independentemente das condições de temperatura que será realizada a seleção clonal. A seleção sequencial de famílias, com intensidades de 60\% (SG) e 60\% (PGC), promoveria maior eficiência da seleção de clones na segunda e terceira geração clonal. No caso de aplicar intensidades mais fortes para aumentar a eficiência da seleção sequencial (GS e PGC), intensidades fracas devem ser aplicadas na GS ( $\geq 60 \%$ ) e mais fortes na PGC $(\geq 40 \%)$. A seleção de famílias para a produtividade de tubérculos poderia ser aplicada na PGC, desde que a seleção de clones individuais não ocorra em condições contrastantes de temperatura.

Termos de indexação: Seleção sequencial, simulação computacional, Solanum tuberosum.

(Received in october 26, 2011 and approved in december 21, 2011)

\section{INTRODUCTION}

Family selection is an alternative to selecting individual clones (mass selection) and for a long time was not been used in clonal propagated species for genetic improvement. One of the reasons for this situation was a lack of precision in the estimation of variances between and within families, and also by the work required to estimate them (SIMMONDS, 1996). Besides, clones are the subject of selection since they can be multiplied to become a new cultivar.
The efficiency of family selection (progeny) over mass selection has been observed in many crops, for example, yield in acerola (PAIVA et al., 2002), yield and other quality components in sugar cane (SKINNER et al., 1987), palm (CEDILLO et al., 2008), pine (REZENDE et al., 1995), rubber (COSTA et al., 2000) and potato (BRADSHAW et al., 1998; SOUZA et al., 2005; BRADSHAW et al., 2009; MELO et al., 2011).

The aim of potato breeding lies in the selection of clones. Therefore, the selection of families would only be

'Universidade Federal de Lavras/UFLA - Departamento de Biologia/DBI - Lavras - MG - Brasil

2Universidade Federal de Lavras/UFLA - Departamento de Biologia/DBI - Cx. P. 3037 - 37200-000 - Lavras - MG - Brasil - cesarbrasil@dbi.ufla.br

Ciênc. agrotec., Lavras, v. 36, n. 1, p. 60-68, jan./fev., 2012 
an initial strategy to reduce the population size and to enable better evaluation of a smaller number of clones in further experimentation. Among the strategies for family selection there is proposal to select among full-sib families of potato at the seedling generation (SG) and the first clonal generation (FCG) for disease resistance, leaving the selection for yield and other low heritability traits for the second and further clonal generations. Bradshaw et al. (1998) and Bradshaw et al. (2009) adapted these proposals by selecting families for disease resistance in SG and selecting clones within families in the FCG. They obtained approximately 130 families, and used selection intensities among families between 20 to $30 \%$ and within families between 6-15\%. With this strategy one recurrent selection cycle was completed in three years, with one harvest per year.

The theoretical models of Casler and Brummer (2008) suggest selection of weaker intensities among families and equal to or stronger intensity within clonal families. However there is a lack of studies to evaluate the most appropriate intensities for families selection in potatoes.

Our objectives were to evaluate the efficiency of family selection in SG and FCG in order to select potato clones adapted to warm temperatures and to determine the selection intensities appropriate to the level of families and individual clones for tuber yield and tuber specific gravity.

\section{MATERIALS AND METHODS}

In the years 2004 and 2005 bi-parental crosses were performed and 30 clonal families, in which one or both parents had heat tolerance, were obtained. The heattolerant parents were obtained by Menezes et al. (2001), Lambert and Pinto (2002) and Simon et al. (2009). All experiments were performed in the experimental area of the Department of Biology at the Universidade Federal de Lavras (UFLA), Lavras, MG, Brazil. In April 2006 the SG was conducted in a greenhouse and, at harvest, only one tuber was selected from each clone and the group of tubers, representing the family, was evaluated for specific gravity.

In December 2006 (rainy season) the FCG was planted in a randomized complete block design with four replications. The plot consisted of 10 plants (clones) in a row, spaced $0.50 \mathrm{~m} \times 0.80 \mathrm{~m}$. The harvest was done separately for each plant and clones were individually identified. Evaluations were made on tuber yield $\left(\mathrm{g} \mathrm{plant}^{-1}\right)$ and the tuber specific gravity ([Weight in air]/[Weight in air - Weight in water]).

In the second clonal generation (SCG) two experiments were planted in September 2008, (rainy season) one for the assessment of families and the other for evaluation of clones. The first was planted in a randomized complete block design with four replications and 10 plants per plot. The traits evaluated in both experiments were the same as in FCG. The second experiment was planted in the augmented block design with three plants per plot and consisted of approximately 750 clones.

In April 2009 (winter crop) a third clonal generation (TCG) was planted in two experiments similar to the SCG. The experiment of families was carried out in a randomized complete block design with four replications and six plants per plot and the experiment of clones was carried out in an augmented block design with four plants per plot. Evaluations were made on 570 clones and same traits as in the SCG were recorded.

In all experiments for the assessments of individual clones, the cultivars Markies, Asterix and Monalisa were used as controls. In the experiments for families evaluations Monalisa was changed for cultivar Atlantic and the other controls were kept the same. Adjusted means of families and clones for each season and also for the joint analysis were calculated. We also estimated the genetic variance and heritabilities among and within families. The broadsense heritability among families $\left(h_{a}^{2}\right)$ was calculated by $h_{a}^{2}=\sigma_{F}^{2} /\left(\sigma_{F}^{2}+\sigma_{e}^{2}\right)$ in which $\sigma_{F}^{2}$ is the genetic variance among families and $\sigma_{e}^{2}$ is the error variance. The variances obtained between plants in the control plots were used as estimates of environmental variance within families and used to calculate the genetic variance of clones within families $\left(\sigma_{W F}^{2}\right)$ as follows: $\sigma_{W F}^{2}=\sigma_{P F}^{2}-\sigma_{W T}^{2}$ where $\sigma_{P F}^{2}$ is the phenotypic variance within families, $\sigma_{W T}^{2}$ is the variance within the controls. The heritability of individual clones $\left(h_{c}^{2}\right)$ was calculated by $h_{c}^{2}=\left(\sigma_{F}^{2}+\sigma_{W F}^{2}\right) /\left(\sigma_{F}^{2}+\sigma_{W F}^{2}+\sigma_{e}^{2}\right)$. For the calculation of variances, we used the method of restricted maximum likelihood (REML) by PROC MIXED of SAS (SAS INSTITUTE, 2000). The confidence intervals for heritability were calculated by Knapp et al. (1985). The realized gain by selection and realized heritability was calculated according to Bernardo (2002).

To simulate the effect of selection of families in the identification of superior clones, classification vectors for the families were created for tuber specific gravity in the SG and tuber specific gravity and tuber yield of tubers in the FCG. Other vectors were created containing the classification of clones for tuber yield or specific gravity, identified by their respective families, using the means of 
individual analysis of SCG and TCG. Various intensities of sequential selection of families (SG and FCG) for tuber specific gravity were also simulated. For all intents and purposes we selected families in SG, and these families were evaluated and selected in the FCG. Subsequently, we verified the participation of these families in individual clones selected in the SCG and TCG.

An algorithm was created in $\mathrm{R}$ language $(\mathrm{R}$ DEVELOPMENT CORE TEAM, 2010) to simulate different intensities for family selection in SG and FCG and various intensities for the selection of clones in the SCG and TCG. The percentage of clones belonging to the selected families was named the incidence of families.

\section{RESULTS AND DISCUSSION}

In vegetative propagated species such as potatoes, the visual selection in early clonal generations of clones ( $\mathrm{SG}$ and FCG) is not efficient and may even represent random selection of clones that will continue in the selection process (BROWN et al. 1987). However, selection based on quantitative traits, such as tuber yield, also is not effective because this trait is largely influenced by seed size (PINTO et al., 1994) and other environmental conditions. Thus, selection only becomes effective from the SCG on when the seed tubers are more uniform in size. The selection of families is a strategy that takes advantage of the information obtained in early generations in order to reduce the number of clones to be evaluated in more advanced generations. Many studies have shown the efficiency of potato family selection under conditions of mild temperatures in the generation SG and FCG for various characters (BRADSHAW et al., 1998; BRADSHAW et al., 2009).

In this study, with simulations of families selection, in general it is observed (Figures 1 to 3 ) that the stronger the intensity of selection of families the lower their participation among the selected clones, regardless of the intensity of clonal selection. On the other hand, the stronger the intensity of selection of clones, the greater the participation of families selected in early generations. Similar results were reported in theoretical simulation studies of selection among and within families by Casler and Brummer (2008). Melo et al. (2011) working from FCG to TCG with potato families, suggested selection intensity from $35 \%$ to $50 \%$ among families and weaker intensity (around 10\%) within families. According to the theoretical model of Simmonds (1996) using 50 families, it has been shown that $10 \%$ of families contain about $60 \%$ of clones with better performance. However, Simmonds considered that the variance among families has the same magnitude as variance within families, which has been shown (BRADSHAW et al., 2009) not to be true. In this study we found that $10 \%$ of superior families represent only $20 \%$ of clones with better performance (Figures 1 to 3 ). This could be due to the small number of families used in this study; maybe with a larger number of families it would be possible to practice stronger intensity of selection among families.
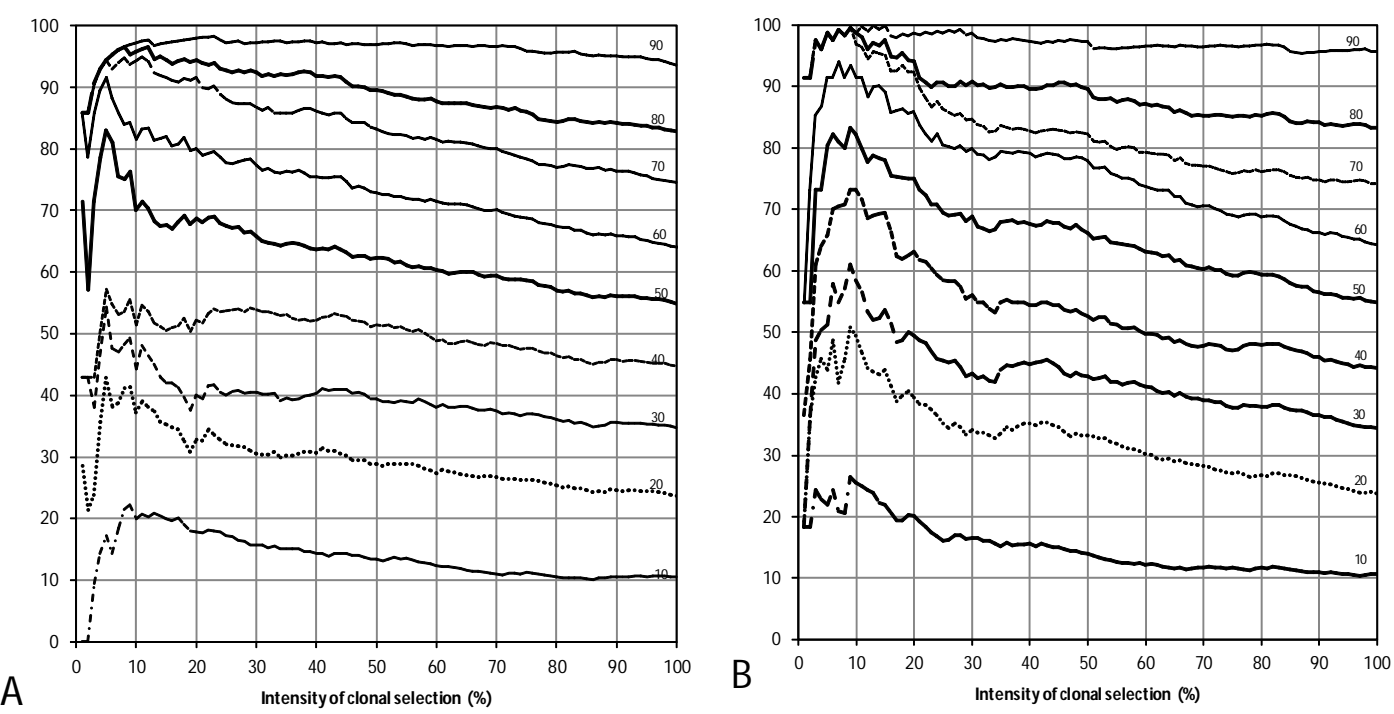

Figure 1 - Incidence of families selected for high specific weight of tubers in the seedling generation on different selection intensities of families (10-90\%) with the effect in the second (A) and third (B) clonal generation. 
In the case of family selection for tuber specific gravity in the SG (greenhouse) efficiency was observed in the selection of clones in both the SCG and in TCG (Figure 1). For example, selecting $50 \%$ of the best families in the SG and $10 \%$ of the best clones in the SCG or TCG, it was found that about $70 \%$ to $80 \%$ of these clones belonged to the selected families (figure 1A and 1B). With family selection intensities of $30 \%$ the incidence of clones dropped to $50 \%$ and $60 \%$ respectively in the SCG and TCG (Figure $1 \mathrm{~A}$ and 1B). The efficiency of family selection for specific gravity in the greenhouse (SG) may have occurred because of the small clone $x$ environment interaction for this trait. While the SCG had been cultivated in the rainy season under high temperatures the TCG was conducted in the winter season with mild temperatures. Similar results were observed for selection of families held only in the FCG (Figure 2). With selection intensities from 50 to $60 \%$ among families and $10 \%$ among clones the incidence of families went from 70 to $80 \%$ in clones selected in SCG or TCG, on the other hand, maintaining $10 \%$ intensity of clone selection and family selection intensities of $20 \%$ resulted in incidences around $40 \%$ of clones (Figure 2A and 2B).

Thus, it is apparent that selection intensities among families of 50 to $60 \%$ provide the best incidence of families and allow the elimination of a reasonable proportion of clones that would not be evaluated in subsequent generations.

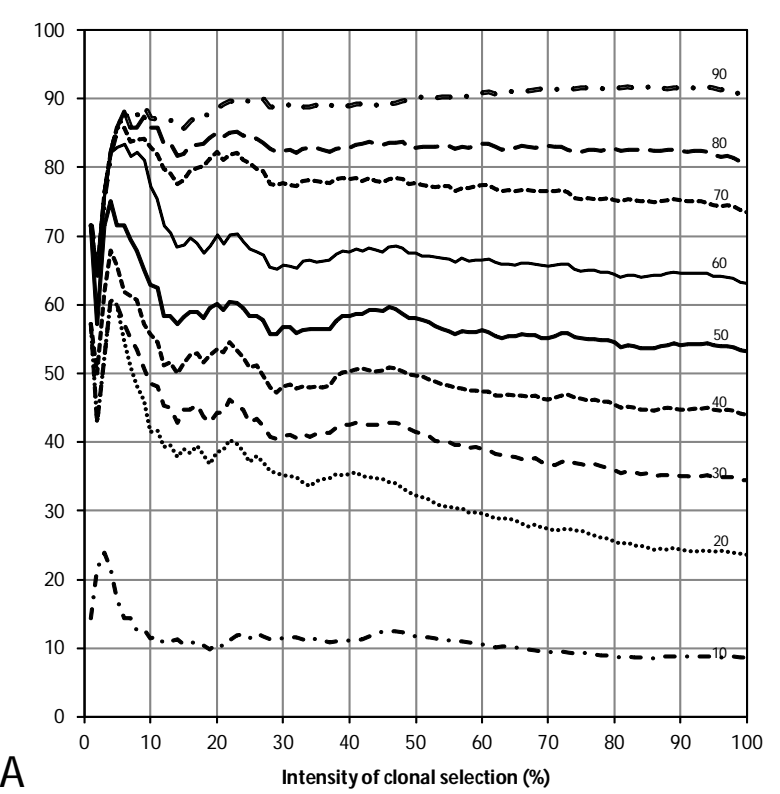

The results discussed refer to the selection of families held only in the SG or FCG. An alternative would be to conduct the selection in the SG and the selected families reevaluated and selected in the FCG (sequential selection). Thus, the final intensity of selection of families is the product of the intensity of selection in each generation. For example, considering the tuber specific gravity a sequential selection of families in SG and FCG resulted in approximately 60 to $75 \%$ incidence of families in selected clones in the SCG or TCG (Figure 3) for intensities of 36\% (60\% in SG and 60\% in FCG) and $10 \%$ intensity of clonal selection. Although the incidence of families in both strategies (screening only in SG and FCG versus sequential selection: SG and FCG) are not very different, sequential selection allows for the elimination of a higher proportion of clones (selection intensity stronger). This indicates that it would be advantageous to use this strategy instead of applying selection of families only to the SG or FCG, besides reducing the size of the experiments on FCG. Therefore, one could make efficient selection of family for tuber specific gravity in both the SG and the FCG with favorable response in the selection of clones in hot or mild temperatures. It was also observed that sequential selection would be more interesting if a weaker selection in SG and a stronger in the FCG were applied (Figure 3). At 60\% selection intensity in SG and 40\% in FCG (final intensity of $24 \%$ ) results showed an incidence of about 50 to $60 \%$ with $10 \%$ selection of clones in the SCG

Figure 2 - Incidence of families selected for high specific weight of tubers in the first clonal generation on different selection intensities of families (10-90\%), with the effect in the second (A) and third (B) clonal generation. 
or TCG However, with intensities of $40 \%$ (SG) and $60 \%$ (FCG) the incidence of families was between 30 to $50 \%$ in the SCG and TCG, respectively.

Figure 4 shows the results of families selection in the FCG for tuber yield. Basically, we observed the same results as those in the selection of families for tuber specific gravity, or in other words, weaker intensities in selection of family allow greater incidence of families. It was also observed that under conditions of higher temperatures (SCG) (Figure 4A), the incidence of families were higher for selection intensities of families at 50 to $60 \%$ ( 70 to $80 \%$ incidence, respectively). In the case of mild temperatures (TCG) the incidence of families for the same selection intensities were $60 \%$ to $65 \%$ (Figure 4B). These results reflect the interaction clone $\mathrm{x}$ environment for tuber yield. The FCG and SCG were cultivated under more similar temperature conditions (rainy season), while the TCG was conducted under milder temperatures (winter crop) than those registered at FCG where the selection of families occurred.

These results indicate that selection of families in FCG aiming at heat tolerance for tuber yield is more efficient when the selection of clones is also performed at higher temperatures.
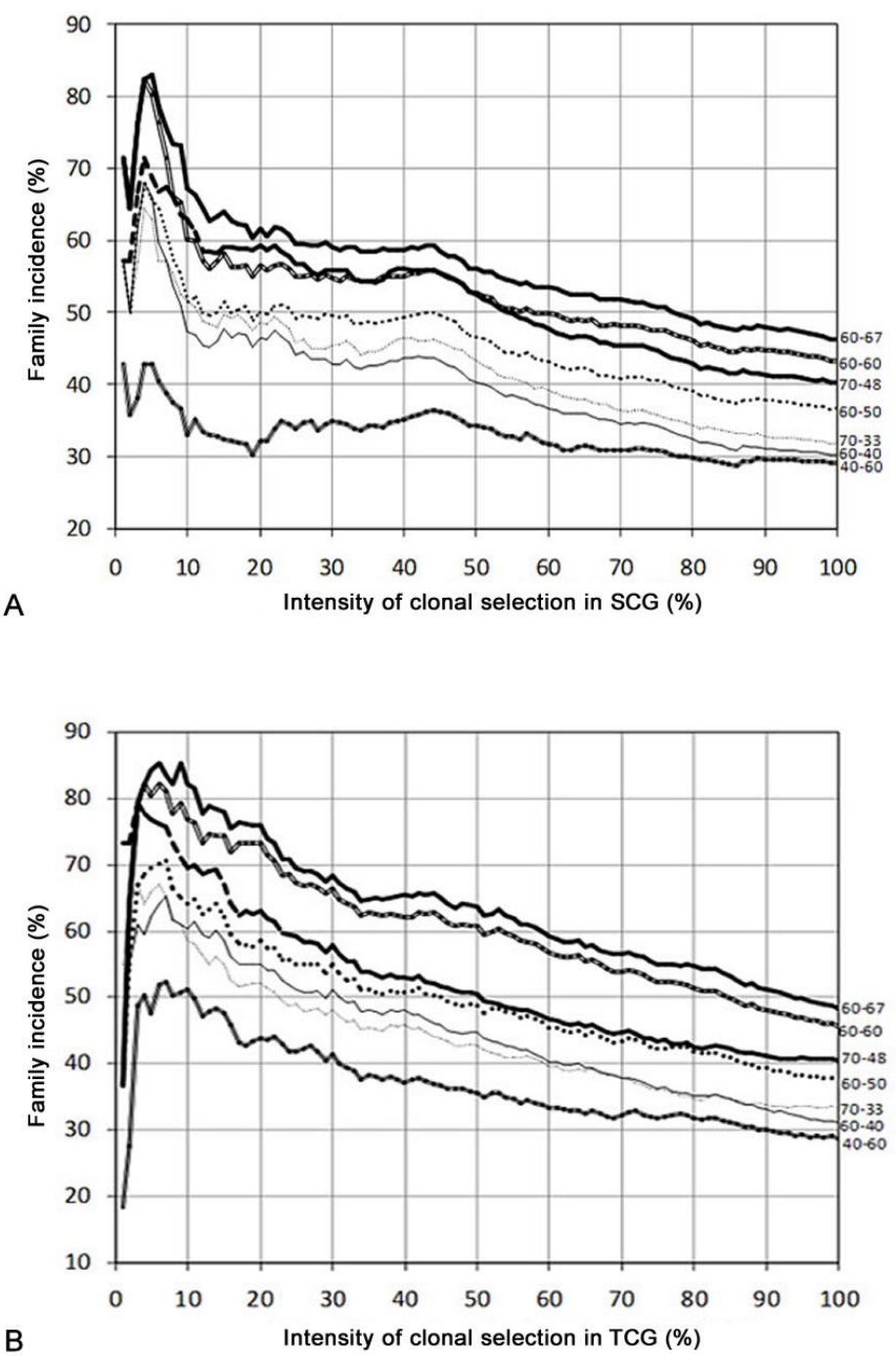

Figure 3 - Incidence of sequential selection of families (seedling and first clonal generation) for high specific weight of tubers on different selection intensities of families with effect in the second [SGC] (A) and third (B) clonal generation [TGC]. The lines represent intensities of families selection in seedling (SG) and first clonal generation FCG. 

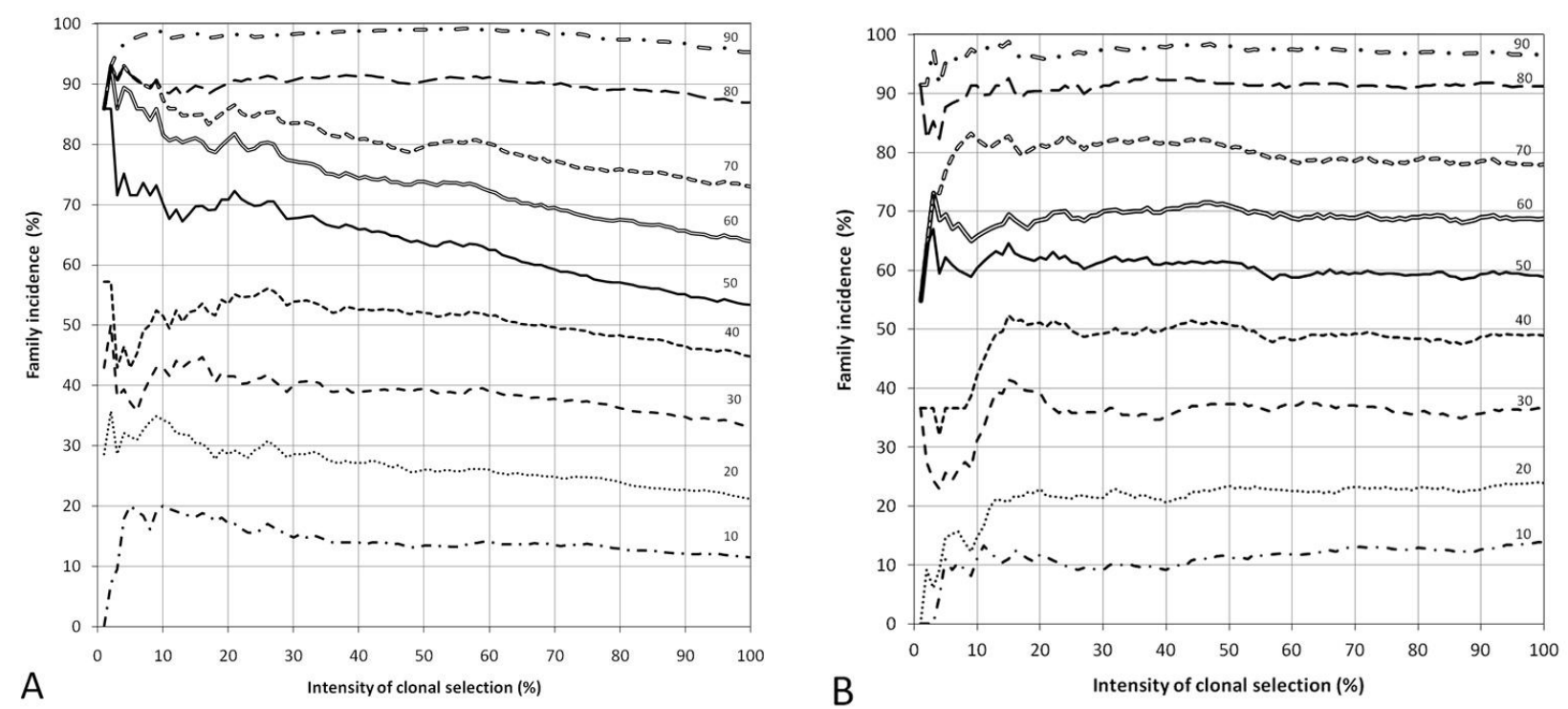

Figure 4 - Incidence of families selected for tuber yield, in the first clonal generation on different selection intensities of families (10-90\%), with effect in the second (A) and third (B) clonal generation.

Another way to visualize the efficiency of family selection is through estimates of $h_{a}^{2}$ (Table 1). The $h_{a}^{2}$ for tuber specific gravity of tubers were higher or similar to $h_{a}^{2}$ for tuber yield depending on generation. Estimates of heritability among families for tuber specific gravity ranged from 0.64 (FCG) and 0.92 (TCG) and for tuber yield between 0.28 (SCG) and 0.80 (FCG). These values are in accordance with other estimates taken from half-sib families for tuber specific gravity: 0.43 (RUTTENCURTER et al., 1979), 0.50 and 0.90 (CAPEZIO et al., 1993), 0.450.83 (MELO et al., 2011) and also for tuber yield (Melo at al. 2011) which ranged from 0.38 to 0.63 . However, in the present study the heritability in the individual clone level was consistently lower, between 0.32 (FCG) and 0.58 (SCG) for tuber specific gravity and 0.01 and 0.19 for tuber yield. This was also observed by Melo et al. (2011) where the $h^{2}$ varied from 0.14 to 0.68 for FCG and TCG productivity and between 0.10 and 0.78 for tuber specific gravity of tubers. These results indicate low efficiency of selection of individual clones in the FCG. For this reason the selection of individuals clones is not recommended for this character (MARTIN 1984;
SWIEZYNSKI 1984; CALIGARI et al., 1986), which reinforces the importance of family selection.

In general, moderate intensities of families selection with stronger intensities of selection within families would promote the selection of superior clones. Therefore, suggestions made by Casler and Brummer (2008) and Hogarth et al. (1997) to assess more families by reducing the number of individuals per family seems more appropriate for potato breeding for heat tolerance. One way to do that is to evaluate a larger number of families with fewer clones (20), while at the same time multiply remaining clones from the families. Once you have made the selection of families, the remaining clones are used in the experiments for clonal selection.

Table 2 shows the realized gains by selection and realized heritability in the TCG. Though the selection was done in the SCG, realized heritabilities at the family level are higher than the selection of individual clones for both characters, indicating the efficiency of families selection. But it also shows that the gains by selection of individual clones are larger when applying high selection intensity (20\%), which has previously been shown by simulations. 
Table 1 - Estimates of heritability and genetic variances among and within families in different clonal generations.

\begin{tabular}{lcccccc}
\hline \multicolumn{1}{c}{ Trait } & $\mathbf{C G}^{\mathbf{1}}$ & $\mathbf{C V}(\boldsymbol{\%})$ & $\sigma_{F}^{2}$ & $\sigma_{W F}^{2}$ & $h_{a}^{2}$ & $h_{c}^{2}$ \\
\hline Yield & 1 & 26.20 & 20167 & - & $0.80(0.64-0.89)$ & 0.12 \\
Specific gravity & 1 & 0.46 & $3.50 \times 10^{-5}$ & - & $0.79(0.62-0.89)$ & 0.32 \\
Yield & 2 & 37.69 & 8058 & 9013 & $0.28(-0.06-0.67)$ & $0.01(-0.57-0.26)$ \\
Specific gravity & 2 & 0.54 & $3.20 \times 10^{-5}$ & $6.1 \times 10^{-5}$ & $0.76(0.65-0.90)$ & $0.58(0.26-0.66)$ \\
Yield & 3 & 31.69 & 7519.99 & 19796 & $0.34(-0.18-0.64)$ & $0.12(-0.39-0.36)$ \\
Specific gravity & 3 & 0.38 & $1.40 \times 10^{-5}$ & $3.8 \times 10^{-5}$ & $0.92(0.65-0.96)$ & $0.51(0.13-0.61)$ \\
Yield & 4 & 31.23 & 20167 & 12262 & $0.71(0.35-0.81)$ & $0.19(-0.27-0.41)$ \\
Specific gravity & 4 & 0.63 & $3.50 \times 10^{-5}$ & $4.3 \times 10^{-5}$ & $0.64(0.49-0.84)$ & $0.48(0.01-0.60)$ \\
\hline
\end{tabular}

${ }^{1}$ CG: Clonal generation; $\sigma_{F}^{2}$ :genetic variance among families; $\sigma_{W F}^{2}$ : genetic variance within families; $h_{a}^{2}, h_{c}^{2}:$ broad sense heritability among families and between individual clones, respectively.

Table 2 - Realized gain and heritability for tuber yield and tuber specific gravity in third clonal generation.

\begin{tabular}{|c|c|c|c|c|c|c|c|}
\hline \multirow[b]{2}{*}{ Generation } & \multirow[b]{2}{*}{$\mathrm{i}$} & \multicolumn{3}{|c|}{ Tuber yield $\left(\mathrm{g} \mathrm{pl}^{-1}\right)$} & \multicolumn{3}{|c|}{ Tuber specific gravity } \\
\hline & & RG & $\mathrm{RG}(\%)$ & $\mathrm{RH}^{2}$ & RG & $\mathrm{RG}(\%)$ & $\mathrm{RH}$ \\
\hline \multirow{3}{*}{$\begin{array}{l}\text { Family } \\
\text { selection }\end{array}$} & 20 & 116.3 & 15.5 & 0.69 & 0.0027 & 0.25 & 0.45 \\
\hline & 40 & 70.7 & 9.4 & 0.56 & 0.0024 & 0.23 & 0.61 \\
\hline & 60 & 30.3 & 4.0 & 0.32 & 0.0009 & 0.08 & 0.32 \\
\hline \multirow{3}{*}{$\begin{array}{l}\text { Clone } \\
\text { selection }\end{array}$} & 20 & 150.8 & 26.6 & 0.33 & 0.0037 & 0.35 & 0.31 \\
\hline & 40 & 87.8 & 15.5 & 0.28 & 0.0026 & 0.24 & 0.34 \\
\hline & 60 & 53.4 & 9.4 & 0.26 & 0.0019 & 0.18 & 0.37 \\
\hline
\end{tabular}

i: intensity of selection; RG: realized gain; $\mathrm{RH}$ : realized heritability.

\section{CONCLUSION}

Family selection intensities between 50 and $60 \%$ showed the greatest gain. Estimates of heritability at the family level were always higher than at the clonal level and corroborate for the more effective selection of families in early generations. The selection of families for tuber specific gravity can be made in the early generations (SG and FCG) regardless of the temperature conditions where the individual clones will be selected. The sequential selection of families with an intensities of $60 \%$ in SG and $60 \%$ in the FCG would promote greater efficiency for the selection of clones in SCG or TCG. In the case of applying stronger selection intensities for a higher efficiency with sequential selection (SG and FCG) weaker intensities should be applied in the $\mathrm{SG}(\geq 60 \%)$ and stronger intensity in FCG $(\geq 40 \%)$. Family selection for tuber yield could be practiced in the first generation as long as the selection of clones was not held in contrasting temperature conditions.

\section{ACKNOWLEDGMENTS}

To CAPES/CNPq- IEL Nacional-Brazil, for the doctoral scholarship from the first author. To Julio C. Ticona Benavente for contributing the programming in $\mathrm{R}$ language used in the simulations. To FAPEMIG by financial resources.

\section{REFERENCES}

BERNARDO, R. Breeding for quantitative traits in plants. Minnessota, Stemma. 2002. 369p.

BRADSHAW, J.E.; DALE, M.F.B.; MACKAY G.R. Improving the yield, processing quality and disease and pest resistance of potatoes by genotypic recurrent selection. Euphytica, Berlin, v. 170, n.1/2, p.215-227, 2009.

BRADSHAW, J.E. et al. Early-generation selection between and within pair crosses in a potato (Solanum tuberosum subsp. tuberosum) breeding programme. Theoretical and Applied Genetics, Berlin, v.97, n.8, p.1331-1339. 1998. 
BROWN, J. et al. The efficiency of visual selection in early generations of a potato breeding programme. Annals of Applied Biology Helsinki, v.110, n.2, p.357-363, 1987.

CALIGARI, P.D.S.; BROWN, J.; ABBOTT, R.J. Selection for yield and yield components in the early generations of a potato breeding programme.

Theoretical and Applied Genetics, Berlin, v.73, n.2, p. 218-222, 1986.

CAPEZIO, S.; HUARTE, M.; CARROZZI, L. Selección por peso específico en generaciones tempranas en el mejoramiento de la papa. Revista Latinoamericana de la Papa, Bogotá, v.5, n.6, p.54-63, 1993.

CASLER, M.D.; BRUMMER, E.C. Theoretical Expected Genetic Gains for Among-and-Within-Family Selection Methods in Perennial Forage Crops. Crop Science, Madison, v.48, n.3, p.890-902, 2008.

CEDILLO, D.S.O. et al. Selection among and within and combined selection in oil palm families derived from Dura $\mathrm{x}$ Dura. Ciência Rural, Santa Maria, v.38, n.1, p. 65-71, 2008.

COSTA, R.B. et al. Seleção combinada univariada e multivariada aplicada ao melhoramento genético da seringueira. Pesquisa Agropecuária Brasileira, Brasilia, v.35, n.2, p.381-388, 2000.

HOGARTH, D.M.; COX, M.C.; BULL, J.K. Sugarcane improvement: past achievements and future prospects. In: . Crop improvement for the 21st century. Louisiana State University, Baton Rouge, 1997, p.29-56.

KNAPP, S.J.; STROUP, W.W.; ROSS, W.M. Exact confidence intervals for heritability on a progeny mean basis. Crop Science, Madison, v.25, n.1, p.192-194, 1985.

LAMBERT, E.S.; PINTO, C.A.B.P. Agronomic performance of potato interspecific hybrids. Crop Breeding and Applied Biotechnology, Viçosa, v.2, n.2, p.179-188, 2002.

MARTIN, M.W. Early generation selection methods for resistance and horticultural factors. American Journal of Potato Research, Orono, v.61, n.7, p. 383-384, 1984.

MELO, D.S. et al. Early selection of potato full-sib families. Ciência e Agrotecnologia, Lavras, v. 35, n. 6, p. 1101-1109, 2011.
MENEZES, C.B. et al. Combining ability of potato genotypes for cool and warm season in Brazil. Crop Breeding and Applied Biotechnology, Viçosa, v.1, n.2, p.145-157, 2001.

PAIVA, J.R. et al. Genetic progress of selections between and within caribbean cherry open pollination progenies. Crop Breeding and Applied Biotechnology, Viçosa, v.2, n.2, p.299-306, 2002.

PINTO, C.A.B.P.; VALVERDE, V.I.R.; ROSSI, M.S. Eficiência da seleção nas primeiras gerações clonais de batata (Solanum tuberosum L.) Pesquisa

Agropecuária Brasileira, Brasilia, v.29, n.5, p.771-778, 1994.

RDEVELOPMENT CORE TEAM. R: a language and environment for statistical computing. Version 12.0, 2010. Available in: http://www.R-project.org. Access in: 15 jan. 2010.

REZENDE, M.D.V. et al. Acuracia seletiva, intervalos de confiança e var de ganhos genéticos associados a 22 métodos de seleção em Pinus caribaea var. hondurensis. Floresta, Curitiba, v.25, n.1/2, p.3-16, 1995.

RUTTENCURTER, G.; HAYNES JUNIOR, F.L.; MOLL, R.H. Estimation of narrow-sense heritability for specific gravity in diploid potatoes (Solanum tuberosum subsp. phureja and stenotonum).

American Journal of Potato Research, Orono, v.56, n.9, p.447-452, 1979.

SAS INSTITUTE. SAS software: User's guide: version 8.2, SAS Institute, Cary, p.291, 2000.

SIMMONDS, N.W. Family selection in plant breeding. Euphytica, Wageningen, v.90, n.2, p.201208, 1996.

SIMON, G.A.; PINTO, C.A.B.P.; BENITES, F.R.G. Seleção de famílias clonais de batata em diferentes ambientes. Ciência e Agrotecnologia, Lavras, v.33, n.1, p.164-169, 2009.

SKINNER, J.C.; HOGARTH, D.M.; WU, K.K. Selection methods, criteria and indices. In: Sugarcane improvement through breeding, Amsterdam, Elsevier, 1987, p.409-453. 
SOUZA, V.Q. et al. Potential of selection among and within potato clonal families. Crop Breeding and Applied Biotechnology, v.5, n.2, p.199-206, 2005.
SWIEZYNSKI, K.M. Early generation selection methods used in polish potato breeding. American Journal of Potato Research, Orono, v.61, n.7, p. 385-394, 1984. 